\title{
Reflections on Ten Years of Preparing Graduate Students for the Professoriate at an American Research University
}

\author{
Samuel Olugbenga King \\ University of Arkansas, USA
}

\begin{abstract}
Using a reflective analysis tool to provide both local and global perspectives, this study focuses on the longitudinal evaluation of the Graduate Student Development (GSD) initiative, the Preparing Future Faculty (PFF) program. The reflection process involves examining the past and present to identify challenges, and culminates in the creation of an action plan to address barriers to further growth and teaching development of graduate students, thus positively impacting student experience. The outcomes of the reflective critique of the PFF program indicate that lack of mentoring, as well as inadequate feedback and funding, are barriers that need to be addressed to positively impact the graduate student experience. Consequently, interventions, such as peer and student evaluations, and alumni surveys are highlighted as pragmatic modes of addressing the inadequate feedback and mentoring barriers. However, funding remains an ongoing challenge. This paper is a contribution to the literature on the use of critical reflection approaches to investigate and evaluate specific programming that focus on enhancing the graduate student experience and development.
\end{abstract}

\section{Introduction}

The local graduate student development (GSD) program, the Preparing Future Faculty (PFF) program at a large research university in the Southeastern United States was created over 10 years ago, based on a national PFF model [1]-[2]. This time lapse presents a strategic window to critically reflect on both the local and national PFF programs, so as to efficiently inform future local PFF design and programming [3]. Moreover, two separate yet interrelated pressures are catalyzing the reflective process on the impact and viability of the local PFF program. First, the Center for Teaching and Learning that hosts and manages the local PFF program is required to produce measures of the effectiveness of the program, in response to the wider institutional quality assurance mandate [4]-[5]. Similarly, a change in management at the Center means that the Center staff is also faced with new expectations about the need to clarify and demonstrate the impact of the PFF program [6]. This paper will therefore be a critical reflection on a GSD program at one university, but with a view to exploring the wider implications for the academy [7].

To illuminate this process, the exploratory reflective framework, the FLOAR heuristic [8] will be adopted as a critical guide for the longitudinal evaluation of the 10 years plus of existence of the local PFF program. The goal is to illuminate how longitudinal reflection can facilitate the quality enhancement of an established GSD program, in order to enhance the graduate student experience.

\section{Methodology: Reflective Inquiry on Local and Global Perspectives}

As a "tool for guided reflection" with local and global units of analysis, the FLOAR framework provides "valuable new perspectives and reframing" on two levels [8, p. 194]. The two units of analysis, local or horizontal, and vertical or global/national, are essentially premised on the use of strategic questioning of program history and structure, together with the challenges and needs, to determine future programming requirements and planning (see Table 1). Moreover, faculty development practitioners have used the tool extensively to critique professional development programs' imperatives and impact $[8, \mathrm{p}$. 185].

The local and national perspective units of analyses of the FLOAR framework examine questions related to program context and history, the scholarship informing program design, identification of program challenges and needs, and how to address them. Based on the FLOAR framework, as outlined in Table 1, the rest of this article is structured sequentially as follows:

- History, Scholarship and Program Structure of the National PFF Program

- History, Scholarship and Program Structure of the Local PFF Program

- Identification of the Local PFF Program Challenges and Needs

- Identification of the National PFF Program Challenges and Needs

- Addressing the National PFF Program Challenges

- Addressing the Local PFF Program Challenges

Hence, the next section will focus on a comprehensive examination of the national PFF program, which is the 
quintessential model for GSD programs in the United States.

\section{History, scholarship and program structure of the national PFF program}

The preparation of graduate students for the professoriate, up into the late 1980s, was woefully inadequate. The preparation basically consisted of graduate students learning mainly through their coursework and dissertation, and hopefully picking up teaching skills and other relevant faculty competencies somehow along that pathway of "accidental occurrences" [1, p. x]. In essence, the completion of a $\mathrm{PhD}$ was the requirement for matriculation into the ranks of the professoriate. This preparation process was implicitly justified because that was how the older faculty learned the tools of the profession, as "the terminal degree is considered sufficient qualification for teaching at the college or university level" [9, p. 1]. The inadequate preparation of graduate students for the professoriate may be summarized as follows [1, pp. 2-7]:

1.The existence of a mismatch between doctoral education and the needs of colleges and universities that employed new Ph.D.s.;

2. Graduate schools and departments seldom gathered data with which to assess their programs;

3. The lack of mobilization or utilization of resources in the academy to help prepare the future professoriate;

4. Changes taking place in faculty roles and in higher education tended to not be reflected in doctoral preparation; and,

5. Hence the graduate student experience, especially in preparing them for future faculty roles, was severely limiting.

To address these deficiencies [1, p. 4], a consortium of two national associations, the Association of American Universities and Colleges (AAU\&C) and the Council for Graduate Schools (CGS), developed a new vision for a comprehensive GSD training model in 1993. The result was the national Preparing Future Faculty (PFF) program, which was designed to be "consistent with the best practices of teaching assistant development, while also advancing another, more comprehensive level of preparation" [1, p. 10]. The PFF program was therefore structured on the premise that graduate students should "begin to develop professional competence in the major responsibilities that faculty members actually have, namely teaching, research and professional service; have learning experiences in the different settings in which the profession is practiced, e.g., colleges and universities with different missions, student bodies and faculty responsibilities; and learn about the complexities of teaching and service in coursework, workshops, and seminars, and by working with mentors in teaching and professional service" $[1, \mathrm{p}$. $\mathrm{x}$ ].

Moreover, the initial PFF program incorporated a pronounced inclusiveness agenda. For example, the "17 original participating universities worked with 68 partner institutions, a group that included nine members of the Association of American Universities, 11 land grant universities, 13 community colleges, eight historically black colleges and universities, six women's colleges" [1, p. 11] and liberal arts institutions. So each participating university (main grantee) in the PFF program (see Table 2) was organized around a cluster, with the inclusion of other institutions, so as to reflect the diversity of American higher education and catalyze the diffusion of ideas and cross-disciplinary, as well as trans-institutional collaboration. Some of the cluster activities included "doctoral students" visits" to participating campuses, "visits to the departments of special interest to the doctoral students; and "ample opportunities for informal conversation with faculty members"[1, p. 22].

Consequently, the Preparing Future Faculty (PFF) program model has been phenomenally successful, and has significantly influenced GSD programs at all categories of higher education institutions, e.g., Ivy League and Research Universities, State Comprehensives, Liberal Arts Colleges, Historically Black Colleges and Universities, in America, e.g., [2]. One enduring artifact of this success is the catalysis of similar PFF programs at universities around the country, subsequent to the completion of the PFF national implementation phases in 2002. For example, the local PFF program that is the main focus of this study was modeled on the national PFF initiative.

\section{History, scholarship, and program structure of the local PFF program}

The local PFF program began in 2004 as a cluster with seven other participating institutions. The other institutions included a community college, a Historically Black University, a master's university, a state comprehensive, two liberal arts colleges, and a private university. The inaugural class at the host institution consisted of 14 graduate students [10].

The core components of the PFF program were the PFF Seminar and the Multi-Campus Practicum. The Seminar was a year-long, pass/fail academic-bearing course, designed to expose graduate students to the realities of teaching, research, and service in higher education. The Multi-Campus Practicum consisted of graduate students making multiple visits to the multiple partner (i.e., cluster) institutions to gain exposure to alternative institutional contexts. The other four components of the Seminar were [10, p. 2]: 
Table 1. An illustration of the FLOAR framework, a longitudinal reflection tool to evaluate professional development programs - adapted from [8]

\begin{tabular}{|l|l|l|}
\hline LOCAL PERSPECTIVE & $\begin{array}{l}\text { GLOBAL/NATIONAL } \\
\text { PERSPECTIVE }\end{array}$ \\
\hline $\mathbf{1}$ & $\begin{array}{l}\text { Program Context } \\
\text { \#History: What is the professional development } \\
\text { program history and/or context? } \\
\text { \#Scholarship: What scholarship has informed } \\
\text { program design, implementation and review? } \\
\text { \#Program Structure: What are the basic elements } \\
\text { or components of the program? }\end{array}$ & $\begin{array}{l}\text { Systemic Issues or Trends } \\
\text { rom a Broader } \\
\text { Perspective }\end{array}$ \\
\hline $\begin{array}{l}\text { STEP } \\
\mathbf{2}\end{array}$ & $\begin{array}{l}\text { \#What is the national history } \\
\text { \#Evaluation: What challenges and/lenges needs have been identified through the program? } \\
\text { evaluation of the program structure, components, and or evolution? }\end{array}$ \\
\hline $\begin{array}{l}\text { STEP } \\
\mathbf{3}\end{array}$ & $\begin{array}{l}\text { Addressing Program Challenges: Intervention Feasibility } \\
\text { \#Action Plan: How may the program challenges and needs be addressed through } \\
\text { meaningful but feasible interventions? }\end{array}$ \\
\hline
\end{tabular}

Table 2. Phases of the national preparing future faculty (PFF) program [1]

\begin{tabular}{|l|l|l|l|}
\hline Dates & Purposes & Funder & Participants \\
\hline $\begin{array}{l}1993- \\
1997\end{array}$ & Develop model programs & $\begin{array}{l}\text { The Pew Charitable } \\
\text { Trusts }\end{array}$ & 17 clusters \\
\hline $\begin{array}{l}1997- \\
2000\end{array}$ & Institutionalize and spread programs & $\begin{array}{l}\text { The Pew Charitable } \\
\text { Trusts }\end{array}$ & 15 clusters \\
\hline $\begin{array}{l}1998- \\
2000\end{array}$ & $\begin{array}{l}\text { Develop model programs in the } \\
\text { sciences and mathematics }\end{array}$ & $\begin{array}{l}\text { National Science } \\
\text { Foundation }\end{array}$ & $\begin{array}{l}20 \text { departments \& } \\
\text { clusters }\end{array}$ \\
\hline $\begin{array}{l}1999- \\
2002\end{array}$ & $\begin{array}{l}\text { Develop model programs in the } \\
\text { humanities and social sciences }\end{array}$ & A private gift & $\begin{array}{l}24 \text { departments \& } \\
\text { clusters }\end{array}$ \\
\hline $\begin{array}{l}2003- \\
\text { Present }\end{array}$ & $\begin{array}{l}\text { Institutional change through model } \\
\text { diffusion }\end{array}$ & $\begin{array}{l}\text { Funding goal: self- } \\
\text { sustaining }\end{array}$ & National \\
\hline
\end{tabular}

Table 3. An illustration of the 10-year evolution of the local preparing future faculty (PFF) program between 2004 and 2014

\begin{tabular}{|c|c|c|}
\hline Program Element & $\begin{array}{l}\text { PFF Program } \\
\text { (2004-2005) }\end{array}$ & $\begin{array}{l}\text { PFF Program } \\
(2014-2015)\end{array}$ \\
\hline Faculty/Facilitator & 1 Tenured Faculty & $\begin{array}{l}1 \text { Tenured Faculty + } 1 \text { Senior } \\
\text { Graduate Teaching Assistant (GTA) }\end{array}$ \\
\hline Enrolment & 14 & 40 \\
\hline Grading & - & Explicit Grading Rubric \\
\hline Course Objectives & General Objectives & $\begin{array}{l}\text { General Objectives + Student } \\
\text { Learning Outcomes }\end{array}$ \\
\hline \multirow{9}{*}{$\begin{array}{l}\text { Changes in } \\
\text { Program } \\
\text { Components }\end{array}$} & Seminar & Seminar \\
\hline & Professional Portfolio & E-Portfolio \\
\hline & $\begin{array}{l}\text { Professional } \\
\text { Development Workshops }\end{array}$ & Professional Development Workshops \\
\hline & Mentoring & - \\
\hline & Multi-Campus Practicum & - \\
\hline & - & $\begin{array}{l}\text { Microteaching + Digital Video \& Peer } \\
\text { Evaluation }\end{array}$ \\
\hline & - & Canvas LMS Discussions (Online) \\
\hline & - & Certificate of Completion \\
\hline & - & New GTA Orientation (Spring/Fall) \\
\hline
\end{tabular}

Table 4. The local and national preparing future faculty (PFF) program challenges

\begin{tabular}{|l|l|}
\hline Local PFF Program Challenges & National PFF Program Challenges \\
\hline $\begin{array}{l}\text { 1. Discontinuity of the Multi-Campus Practicum } \\
\text { (i.e., lack of institutional clusters), due to funding }\end{array}$ & \multirow{2}{*}{ Availability of funding to support } \\
inclusive institutional clusters \\
2. Lack of structured mentoring for graduate & \\
students & $\begin{array}{l}\text { 3. Inadequate feedback to support graduate } \\
\text { students' 'teaching development (e.g., } \\
\text { microteaching) }\end{array}$ \\
\hline
\end{tabular}


- Individual Contracts: Development of individual contracts (written plans) by graduate students to address areas of personal interest, with focus on up to five areas of interest, including teaching skills, diversity of learners and learning styles, research, instructional technology, faculty roles and rewards, etc;

- Professional Portfolio: Documentation of teaching, research and outreach philosophies, activities and effectiveness;

- Professional Development Workshops: Participation of graduate students in the other professional development programs convened by the Center, such as the Small Group Instructional Feedback (SGIF) and professional development seminars on relevant teaching and learning topics, as well as Brown Bag seminars;

- Mentoring: Participants received mentoring from faculty from their institutions, including the cluster graduate students.

There were a total of at least 20 contacts hours for the course, with the program participants spending at least one hour on the Multi-Campus Practicum for each two hours spent on the Seminar activities.

\subsection{Overview of the Current (2014-2015) Local PFF Program Structure}

Between 2004 and 2014, enrolment in the PFF program more than doubled from 14 to 40 students. The main component of the PFF program, 10 years after the freshman class in 2004, is still the Seminar, a year-long pass/fail and credit-bearing graduate course at the University [11]. However, the Multi-Campus Practicum and Mentoring are no longer a part of the PFF program, due mainly to funding constraints (see Table 3). Further, Individual Contracts have been streamlined and integrated into Professional Portfolio, which is now E-Portfolio, as it is web-based, following standard practice in the field; E-Portfolio is also the focus of the University's Quality Enhancement Plan for Southern Association of Colleges and Schools (SACS) re-accreditation. The other changes include the addition of a Microteaching component, including digital video recording and peer feedback; and online group discussion on the learning management system, Canvas. These changes were also informed by standard practice in the GSD literature [12]-[13]. The other explicit modifications include the incorporation of Student Learning Outcomes, into the official course outline, in addition to the General Objectives; and the Grading Rubric for the course. A comparison of the initial (2004-2005) and current (2014-2015) program structures is presented in Table 3.

\section{Identification of the local PFF program challenges and needs}

In general, five evaluation approaches are relevant for identifying the local PFF program challenges and needs, and these are:

1. Evaluation based on Proof of Concept;

2. Evaluation based on the Best Practices Literature;

3. Evaluation based on Reflection on the Initial and Current Program Structure;

4. Evaluation based on Specific (Cross-Sectional) Evaluation Measures; and

5. Evaluation of Teaching: Microteaching and Feedback.

\subsection{Evaluation Based on Proof of Concept}

One of the core goals of the national PFF program was to extend "PFF programs throughout institutions" $[1$, p. 52] in the United States by, among others, integrating them into doctoral programs. Hence the creation of the local PFF program based on the national model, including the incorporation of academic credit-bearing courses and certificates of program completion, can be considered a successful proof of concept [14]. The challenge for the proof-ofconcept evaluation mode is to establish concept or program sustainability, and this goal has been met. So the other evaluation approaches, particularly reflections on the initial and current program structures, and the use of cross-sectional evaluation measures, are particularly relevant to identifying current program challenges and needs.

\subsection{Evaluation based on the Best Practices Literature}

Shore recommended that "One indicator of quality for a GTA program is that it follows best practices. It offers training that is comparable to other GTA programs and that has been demonstrated to be effective" [15, p. 181]. As was earlier stated, the local PFF program began as an extension of the national PFF program, which was carefully designed and implemented based on recommendations about best practices from two national university associations to address the lack of development programs for graduate students nationally. The local PFF program structure and components have also considerably drawn from the scholarship on best practices in the field [16], [17].

For example, the newer components of the program, the pairing of microteaching with digital video recording and peer evaluation, and the extensive use of E-Portfolios, are based on relevant recent research [17]. For example, Border and Von Hoene concluded that "the single most pervasive change in 
the programming offered for graduate students since the early 1990s is in the area of developing teaching portfolios to document and improve teaching" [18, p. 336]. Similarly, other studies, e.g., [3], [12]-[13], [19]-[20], highlight how the use of video together with peer evaluation and faculty consultation can produce significant positive effects on graduate student learning and development outcomes. Additionally, graduate students can link to the videos in their applications to potential employers.

Moreover, the local PFF program has been proactive in addressing some of the topics that the research literature indicates are not being sufficiently addressed in GSD preparation programs [21]. These topics include the use of electronic technologies and audiovisual equipment [21, p. 28], job interview preparations, teaching philosophy development, and research grant writing [21, p. 35].

\subsection{Evaluation Based on Reflection on the Initial and Current Program Structure}

A comparison of the initial and program structure (see Table 3) shows that while there are similarities, there are also a few differences between the program implementation in 2004 and 2014. Moreover, some of these differences give rise to new challenges. For example, graduate students are no longer being exposed to learning, development and practices in alternative institutional contexts due to the discontinuation of the Multi-Campus Practicum component of the local PFF program. Similarly, the Mentoring component is no longer being offered, and this means that one of the most impactful graduate student developmental framework is missing in the current program structure [22], [23]; [13, p. 10]. Mentoring is also beneficial to participating faculty. One of the findings of the national PFF program leadership was that "faculty members who serve as mentors gain mentors gain renewed vitality and professional development from working with advanced graduate students" [1, p. xi].

\subsection{Evaluation Based on Specific (Cross- Sectional) Evaluation Measures}

A selection of quantitative and qualitative measures, including surveys and focus groups, have been used to evaluate the impact of the local PFF program on the development of the graduate student participants. For example, at least $50 \%$ of respondents indicated that participation in the program has significantly prepared them to teach and seek grant funding [16], [17]. This is an indication that the PFF program has been considerably successful.

\subsection{Evaluation of Teaching: Microteaching and Feedback}

Feedback has also been identified as a key challenge to increasing the program's effectiveness and impact on continued graduate student development. Specifically, the PFF program participants requested individual and real time feedback on their microteaching sessions, in addition to the real time peer feedback mode; they also requested individual feedback on the Teaching Philosophy, Research Statements, and E-Portfolio artifacts [16]. The need for individual and immediate feedback has been identified as a missing link in the graduate student development literature. For example, [13] indicated that an unresolved issue in GSD programs is "the form of feedback (written or verbal), the amount of feedback, and the amount of positive or critical feedback that is appropriate" [13].

So, the main future challenge is how to manage or expand class time, so as to incorporate immediate, personalized feedback into the microteaching session to support the teaching development and exposure of graduate students. The need to address this challenge is particularly important because microteaching, as supplemented by video recording and peer evaluation, has become a central component of the local PFF program, due the varied benefits of microteaching. Microteaching is a resourceful approach to give graduate students opportunities to practice and develop their teaching skills, given the multiple demands on their time [32, p. 41]. Staton and Darling [33] commented that the "time demands of being either an effective teacher or an outstanding student are stringent and often overwhelming, and TAs must maintain a constant balance between the two tasks" [33, p. 15].

Further, microteaching also helps minimize or mitigate teaching anxiety [34-36]. One faculty development practitioner reflected:

"In my many years of working with new GTAs, I found that having GTAs prepare a lesson (with guidance and feedback from experienced instructors) and present that lesson (while peers act as students) helps them figure out some of the nuts and bolts of teaching (e.g., pacing of content, how to move around the classroom, what voice level and inflection to use). In addition, watching a video of their teaching and receiving feedback from both peers (acting as students) and a veteran instructor on their lesson preparation provides new GTAs more stress relief than anything else we have done.".

$[37$, p. 23]

\section{Identification of the national PFF program challenges and needs}

The following four challenges were identified over 15 years ago [1, pp. 49-57] as being key to 
sustaining the growth and further development of the post-2002 national PFF Program (see Table 2):

1. Sustaining the clusters (Inclusiveness);

2. Integrating PFF into doctoral programs;

3. Extending PFF programs throughout institutions; and

4. Providing financial support.

\subsection{Sustaining the Clusters (Inclusiveness)}

As previously highlighted, the 1993-2002 phase of the national PFF program, as well as the immediate post-2002 (2003-present) broader diffusion phases, were very successful in the establishment of clusters that involved partnerships between diverse institutions. The clusters were a reflection of the stratified landscape of higher education in the United States. The initial local PFF cluster, which was a seven-institution partnership, was an example of the success of the cluster initiative. But similar to the experience of the local PFF program, the evidence indicates that clusters are no longer a main feature of PFF programs. One indication of this trend is the fact that most GSD programs are predominantly hosted at research universities [24, p. 11], [18, p. 338], [25, p. 218-219].

As such, graduate students are not being introduced to insights about the academy other than their own institutional contexts. This is a major challenge, as one of the core benefits of the PFF program was this cross-institutional exposure, as one alumnus, a Math graduate teaching assistant (GTA) commented:

"I have heard insights from faculty at other institutions, who are perhaps more likely to have experimented with alternative teaching techniques, such as the use of computers in the classroom for calculus reform projects."

[1, p. 40]

\subsection{Integrating PFF into Doctoral Programs and Extending PFF Programs throughout Institutions}

The post-2002 phase of the national PFF program has been a significant success regarding uptake. Many GSD preparation programs now incorporate elements of the PFF program, e.g., academic credit-bearing courses into their doctoral programs [2]; see also [24, p. 10], [18, pp. 328-329], [25, p. 218]. This suggests that institutional practices regarding GSD programs have been positively influenced by the national PFF initiative. As previously highlighted, the ongoing challenge is to ensure further diffusion and sustainability of programs at a greater range of universities and colleges, e.g., state comprehensive universities and community colleges, and historically Black colleges and universities (HBCUs).

\subsection{Providing Financial Support}

Funding, or more accurately, lack of grant or institutional funding, is a major barrier to sustaining some of the more innovative aspects of the PFF program. For example, the management of PFF clusters often required the services of a full time Cluster Coordinator [1, p. 21], which requires considerable capital investment. Similarly, significant funding is required to facilitate multi-campus visits for local PFF participants $(n=40)$. It is instructive to note that the national PFF initiative was catalyzed by a $\$ 1$ million seed grant:

"In the first phase of this [national PFF] program, grants totaling about $\$ 1$ million were awarded to 17 research universities to develop models of more effective ways to prepare doctoral students for the professoriate." [1, p. 10]

An additional benefit of the availability of grants is that faculty can use them to procure time, a scarce resource, e.g., [26, p. xi], to devote to graduate student teaching development and mentoring. Meanwhile, a consequence of the recent US economic recession is the reduction in the availability of teaching development grants, e.g., [27, p. 8] and by extension, a slight increase in competitiveness for grants.

The authors [1] summarized the importance of funding by concluding that "failing to make the transition from grant support to institutional support is perhaps the most common reason for the failure of innovations that are supported by external funds" [1, p. 54]. So while the national PFF program has been phenomenally successful in changing institutional practices regarding student development and preparation, a significant challenge is the availability of funding to support the inclusive institutional clusters' framework.

\section{Addressing the national PFF program challenges}

There does not appear to be a coherent grant scheme, within the current funding climate, to encourage or address the paucity of inclusive institutional clusters in which to embed graduate students' training and preparation. Moreover, the time and effort required in pooling multi-institutional resources to apply for collaborative grants are often mitigated by the low grant success rates. For example, the success rates for all groups of applicants for the National Science Foundation grant schemes [27, p. 8], a major funding agency in the United States, experienced a significant decline between 2001 and 2013 (see Figure 1). Anecdotal evidence indicates that grant funding and success rates are perhaps worse in the Humanities. Access to funding is one reason perhaps why there has been a trend towards an 
exclusive focus on localized, non-clustered PFF programs.

\section{Success Rates for NSF Grants}

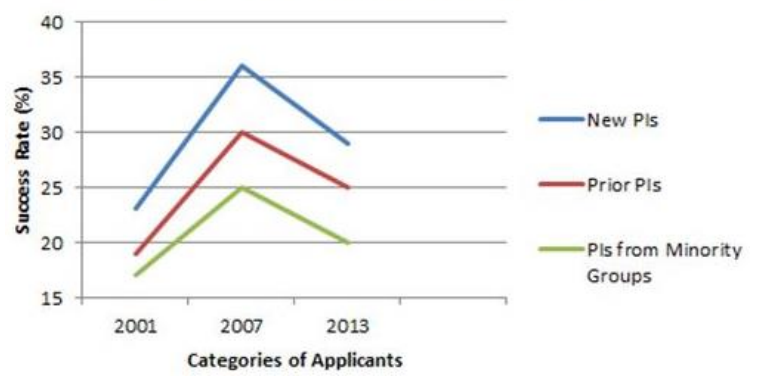

Figure 1. NSF grants' success rates between 2001 and 2013 [27]

\section{Addressing the local PFF program challenges}

Three main challenges were identified as barriers to be overcome to further enhance the effectiveness of the local PFF program (see Table 4).

The lack of institutional clusters challenge is related to the national trend, and is therefore also a lack of adequate resource issue. However, both the lack of structured mentoring, and inadequate feedback to support graduate students' development can be sufficiently addressed through a combination of the following quality enhancement approaches:

- Mentoring: Streamlined mentoring based on face time with PFF faculty, e.g., through time-efficient and integrated learning communities, to maximize faculty time;

- Alumni Surveys: The use of alumni surveys to provide another longitudinal measure of the PFF program impact [21, p. 36], [1, p. 5];

- E-Portfolios: Peer evaluation of the studentproduced E-Portfolios, with the time spent on peer feedback process counting towards the overall Seminar grade;

- Peer Feedback: The review of the current paperbased microteaching peer evaluation tool, so that peers can provide actionable and specific feedback to one another after each video-recorded microteaching session or class; for example, through peer feedback on student-produced microteaching videos, with the time spent on video viewing and commenting incorporated into the Seminar grading scheme;

- Self-Reflection: Individual reviews of participation in Professional Development Seminars, as well as development of e-Portfolios, Research Statements, and Teaching Philosophies, followed by a one-page self-reflective, critical commentary;

- Student Evaluations: The promotion and emphasis of the Small Group Instructional Feedback (SGIF) program [28], as a central component of the GSD program. The SGIF program is available to the PFF participants through the host Center's professional development programming. Some graduate students have previously received personalized and actionable feedback on their teaching through this Instructional Feedback program, but the program does not appear to be perceived as being critical to the graduate students' teaching development.

\section{Conclusion}

This paper has addressed the issue of the quality enhancement of GSD programs by critically investigating the PFF program through the adoption of a longitudinal reflection tool. The FLOAR framework has enabled both local and global evaluation perspectives on the PFF program, which have provided critical information on the challenges that the local and national PFF programs have to overcome for further development and positive enhancement of the graduate student experience.

Based on the longitudinal reflection process, lack of mentoring and inadequate feedback were identified as the two barriers that can be realistically addressed to enhance graduate students' experience and preparation for future faculty roles. A number of meaningful but feasible quality enhancement approaches, including peer and formative evaluations, alumni surveys, and e-Portfolios, are subsequently outlined as measures to address the inadequate feedback and mentoring challenges. Similarly, funding was identified as a major barrier to sustaining innovative but inclusive PFF institutional clusters to expose graduate students to alternative GSD experiences and developmental frameworks.

This article has been written with the expectation that academic developers working in the field of graduate students' preparation "have a scholarly responsibility to share our work and the evidence of its effectiveness with others" [29, pp. 83-84]. Further, the use of a systematic longitudinal reflection process, the FLOAR framework, has been adopted for this study based on the need for systematic evaluation [30, p. 107], and the potential of the tool to help GSD program developers, faculty and other staff to "imagine possibilities and take new perspectives on our work, allowing us to contribute to, and perhaps even to lead, positive change at our institutions and in higher education" [8, p. 195] by elevating the graduate student experience. This is particularly relevant for those tasked with the leadership of GSD programs because "the job of leading and managing an academic development unit leaves little time for reflecting on our own experiences and learning" [29, p. 84]. This paper is therefore presented as one approach to addressing the quality enhancement of 
GSD programs through the lens of systematic reflection [31, p. 176].

\section{Acknowledgments}

This is to acknowledge the helpful critique provided by Drs. Diane E. Boyd and Gisela BuschleDiller on the initial draft of this article. The local PFF program, which is a main focus of this article, was developed by Dr. J.E. Groccia of the Biggio Center for the Enhancement of Teaching and Learning at Auburn University in 2004. Meanwhile, Dr. Gisela Buschle-Diller, assisted by Ms. Elizabeth Hancock, has continued the outstanding local PFF programming being offered to enhance the graduate student experience.

\section{References}

[1] Gaff, J. G.; Pruitt-Logan, A. S.; Weibl, R. A. (2000). Building the faculty we need: Colleges and universities working together. Washington, DC: Association of American Colleges and Universities (AAC\&U).

[2] Denecke, D. D.; Kent, J.; Wiener, W. (2011). Preparing future faculty to assess student learning. Washington, DC: Council of Graduate Schools.

[3] Brookfield, S. D. (1995). Becoming a Critically Reflective Teacher. San-Francisco: Jossey-Bass.

[4] Pratasavitskaya, H., Stensaker, B. (2010). Quality management in higher education: Towards a better understanding of an emerging field. Quality in Higher Education, 16(1), 37-50.

[5] Buller, J. L. (2012). Best practices in faculty evaluation: A practical guide for academic leaders. San Francisco: Jossey-Bass.

[6] Gray, K.; Radloff, A. (2008). The idea of impact and its implications for academic development work. International Journal of Academic Development, 13(2), 97-106.

[7] Turner, D. A. (2011). Quality in higher education. Comparative and International Education: A Diversity of Voices, 10. Boston: Sense.

[8] Felten, P.; Little, D.; Ortquist-Ahrens, L.; Reder, M. (2013). Program planning, prioritizing, and improving: A simple heuristic. To Improve the Academy, 32, 183-198.

[9] Benassi, V. A.; Buskist, W. (2012). Preparing the new professoriate to teach. In William Buskist; Victor A. Benassi (Eds.), Effective college and university teaching: Strategies and tactics for the new professoriate (pp. 1-8). Washington DC: Sage.

[10] Groccia, J. E. (2004). Preparing Future Faculty Seminar I/II. Biggio Center for the Enhancement of Teaching and Learning, Auburn University, Auburn, Alabama. Microsoft Word File.

[11] Buschle-Diller, G. (2014). Preparing Future Faculty Seminar I/II. Biggio Center for the Enhancement of Teaching and Learning, Auburn University, Auburn, Alabama. Microsoft Word File.

[12] Howard, C. R. (2012). Technology in higher education. In William Buskist; Victor A. Benassi (Eds.), Effective college and university teaching: Strategies and tactics for the new professoriate (pp. 163-172). Washington DC: Sage.

[13] Abbott, R. D.; Wulff, D. H.; Szego, C. K. (1989). Review of research on TA training. In J. D. Nyquist; R. D. Abbott; D. H. Wulff (Eds.), Teaching assistant training in the 1990s (pp. 111-124). San Francisco, CA: Jossey-Bass.

[14] Borko, H. (2004). Professional development and teacher learning: Mapping the terrain. Educational Researcher, 33(8), 3-15.

[15] Shore, C. M. (2012). Assessing the effectiveness of GTA preparatory activities and programs. In W. Buskist; Victor, A. Benassi (Eds.), Effective college and university teaching: Strategies and tactics for the new professoriate (pp. 99-106). Thousand Oaks, CA: SAGE Publications, Inc.

[16] Boyd, D. E.; Jescovitch, L.; Hancock, E. (2015). Auburn University's preparing future faculty (PFF) program: Supporting the advancement of STEM future faculty. Poster presented at the meeting of the Center for the Integration of Research, Teaching, and Learning (CIRTL) Network Forum, College Station, Texas.

[17] Wang, C. (2013). Preparing future faculty programs and Boyer's four domains of scholarship. Unpublished Doctoral Dissertation, Auburn University, Auburn, Alabama.

[18] Border, L. B. L.; Von Hoene, L. M. (2010). Graduate and professional student development programs. In Kay J. Gillespie; \& Douglas L. Robertson (Eds.; 2nd ed.), A guide to faculty development (pp. 327-346). San-Francisco: JosseyBass.

[19] Warren, L. (2002). Methods for addressing diversity in the classroom. In K. H. Gillespie; L. R. Hilsen; E.C. Wadsworth (Eds.), A guide to faculty 
development: Practical advice, examples, and resources (pp. 214-226). San-Francisco: Jossey-Bass.

[20] Dalgaard, K. A. (1982). Some effects of training on teaching effectiveness of untrained university teaching assistants. Research in Higher Education, 17(1), 39-50.

[21] Silvestri, M. M.; Cox, B. D.; Buskist, W.; Keeley, J. W. (2012). Preparing for the transition from graduate school to the academy: An exemplar from psychology. In William Buskist; Victor A. Benassi (Eds.), Effective college and university teaching: Strategies and tactics for the new professoriate (pp. 27-38). Washington DC: Sage.

[22] Boyle, P.; Boice, B. (1998). Systematic mentoring for new faculty teachers and graduate teaching assistants. Innovative Higher Education, 22, 157-179.

[23] Gaia, C. A.; Corts, D. P.; Tatum, H. E.; Allen, J. (2003). The GTA mentoring program: An interdisciplinary approach to developing future faculty as teacher-scholars. College Teaching, 51, 6165.

[24] Ouellett, Matthew, L. (2010). Overview of faculty development: History and choices. In Kay J. Gillespie; Douglas L. Robertson (Eds.; 2nd ed.), A guide to faculty development (pp. 3-20). SanFrancisco: Jossey-Bass.

[25] Brennan, K. M.; Cruz, L.; Kinner, F. B. (2013). From outsiders to insiders: Graduate assistant development at comprehensive state universities. To Improve The Academy, 32, 217-234.

[26] Boyer, E. L. (1997). Scholarship Reconsidered: Priorities of the professorate. San Francisco: JosseyBass.

[27] National Science Foundation. (2014). Report to the National Science Board on the National Science Foundation's merit review process - fiscal year 2013 (NSB-14-32). Washington, DC: U.S. Government Printing Office.

[28] Ward, B. A. (1987). Instructional grouping in the classroom. School Improvement Research Series, 2, $1-17$.

[29] Brew, A.; Peseta, T. (2008). International Journal of Academic Development, 13(2), 83-85.

[30] Bamber, V. (2008). Evaluating lecturer development programmes: Received wisdom or selfknowledge? International Journal of Academic Development, 13(2), 107-116.
[31] Land, R. (2011). There could be trouble ahead: Using threshold concepts as a tool of analysis. International Journal of Academic Development, 16(2), 175-178.

[32] Prentice-Dunn, S. (2012). Teaching in the context of professional development and work-private life balance. In William Buskist; Victor A. Benassi (Eds.), Effective college and university teaching: Strategies and tactics for the new professoriate (pp. 39-47). Washington DC: Sage.

[33] Staton, A.Q.; \& Darling, A.L. (2009). Socialization of teaching assistants. In J. D. Nyquist; R. D. Abbott; D. H. Wulff (Eds.), Teaching assistant training in the 1990s (pp. 15-22). San Francisco, CA: Jossey-Bass.

[34] Hart, N.I. (1987). Student teacher anxieties: Four measured factors and their relationships to pupil disruption in class. Educational Research, 29, 12-18.

[35] Houlihan, M.; Fraser, I.; Fenwick, K.D.; Fish, T.; $\&$ Moeller, C. (2009). Personality effects on teaching anxiety and teaching strategies in university professors. Canadian Journal of Higher Education, 39(1), 61-72.

[36] Strong, C.E. (2013). Music performance anxiety and teaching anxiety: A review of the literature and implications for music education (Unpublished Master's Thesis). Ball State University, Muncie, Indiana.

[37] Lucas, S.G. (2012). Allaying graduate student fears about teaching. In William Buskist; Victor A. Benassi (Eds.), Effective college and university teaching: Strategies and tactics for the new professoriate (pp. 17-26). Washington DC: Sage. 